medRxiv preprint doi: https://doi.org/10.1101/2021.07.05.21260026; this version posted July 7,2021 . The copyright holder for this preprint

(which was not certified by peer review) is the author/funder, who has granted medRxiv a license to display the preprint in perpetuity.

It is made available under a CC-BY-NC-ND 4.0 International license.

\title{
Ethnic disparities in hospitalisation and hospital-outcomes during the second wave of COVID-19 infection in east London
}

Y I Wan PhD, ${ }^{1,2}$ V J Apea MB BS, ${ }^{3,4}$ R Dhairyawan MB BS, ${ }^{3,4}$ Z A Puthucheary PhD, ${ }^{1,2}$ R M Pearse MD, ${ }^{1,2} \mathrm{C}$ M Orkin MB BCh, ${ }^{3,4} \mathrm{~J}$ R Prowle MD, ${ }^{1,2}$

${ }^{1}$ William Harvey Research Institute, Queen Mary University of London, London, UK, EC1M 6BQ.

${ }^{2}$ Acute Critical Care Research Unit, Royal London Hospital, Barts Health NHS Trust, London, UK, E1 1FR.

${ }^{3}$ Blizard Institute, Queen Mary University of London, London, UK, E1 2AT.

${ }^{4}$ Department of Infection and Immunity, Royal London Hospital, Barts Health NHS Trust, London, UK, E1 1FR.

*Correspondence to

Yize I Wan $\mathrm{PhD}$,

Adult Critical Care Unit,

The Royal London Hospital,

Whitechapel

London E1 1FR

Email: yize.wan@qmul.ac.uk

Tel: +44 20359440351

Abstract: 274 words

Main text: 3495 words

Keywords: ethnicity, ethnic diversity; socioeconomic factors, health disparities; inequities; survival, COVID-19 
medRxiv preprint doi: https://doi.org/10.1101/2021.07.05.21260026; this version posted July 7,2021 . The copyright holder for this preprint (which was not certified by peer review) is the author/funder, who has granted medRxiv a license to display the preprint in perpetuity. It is made available under a CC-BY-NC-ND 4.0 International license.

\begin{abstract}

\section{Objectives}

To determine if changes in public behaviours, developments in COVID-19 treatments, improved patient care, and directed policy initiatives have altered outcomes for minority ethnic groups in the second pandemic wave.
\end{abstract}

\title{
Design
}

Prospectively defined observational study using registry data.

Setting

Four acute NHS Hospitals in east London.

\section{Participants}

Patients aged $\geq 16$ years with an emergency hospital admission with SARS-CoV-2 infection between $1^{\text {st }}$ September 2020 and $17^{\text {th }}$ February 2021.

\section{Main outcome measures}

Primary outcome was 30-day mortality from time of index COVID-19 hospital admission. Secondary endpoints were 90-day mortality and need for ICU admission. Multivariable survival analysis was used to assess associations between ethnicity and mortality accounting for predefined risk factors. Age-standardised rates of hospital admission relative to the local population were compared between ethnic groups.

\section{Results}

Of 5533 patients, the ethnic distribution was White $(\mathrm{n}=1805,32.6 \%)$, Asian/Asian British ( $\mathrm{n}=1983,35.8 \%)$, Black/Black British $(n=634,11.4 \%)$, Mixed/Other $(n=433,7.8 \%)$, and unknown $(n=678,12.2 \%)$. Excluding 678 patients with missing data, 4855 were included in multivariable analysis. Relative to the White population, Asian and Black populations experienced 4.1 times (3.77-4.39) and 2.1 times (1.88-2.33) higher rates of agestandardised hospital admission. After adjustment for various patient risk factors including age, sex, and socioeconomic deprivation, Asian patients were at significantly higher risk of death within 30 days (HR 1.47 [1.24-1.73]). No association with increased risk of death in hospitalised patients was observed for Black or Mixed/Other ethnicity.

\section{Conclusions}

Asian and Black ethnic groups continue to experience poor outcomes following COVID-19. Despite higher-thanexpected rates of admission, Black and Asian patients experienced similar or greater risk of death in hospital, implying a higher overall risk of COVID-19 associated death in these communities. 
medRxiv preprint doi: https://doi.org/10.1101/2021.07.05.21260026; this version posted July 7,2021 . The copyright holder for this preprint

(which was not certified by peer review) is the author/funder, who has granted medRxiv a license to display the preprint in perpetuity. It is made available under a CC-BY-NC-ND 4.0 International license.

\section{Strengths and limitations of this study}

- This study represents one of the largest descriptors of outcomes in minority ethnic patients with COVID-19 distinguished by the majority ethnically diverse cohort within a catchment area of approximately one million people in the east of London.

- Large absolute numbers of patients drawn from a single geographic region and treated within the same hospital system minimize many of the geographic biases present within other studies including the impact of variation in transmission risk.

- Our analyses are strengthened by adherence to a prespecified analysis plan, inclusion of a detailed baseline, comorbidity, and COVID-19 risk factors in multivariable modelling, and sensitivity tests using different measures of comorbidity.

- However as with all observational studies, not all potential contributing risk factors could be assessed, including other measures of baseline health status such as nutritional or lifestyle influences as well as contextual factors such as household composition and occupation.

- We were not able to include suspected but not proven COVID-19 cases or community cases not requiring hospital admission or the effect of the differing viral strains in the first and second wave. 
medRxiv preprint doi: https://doi.org/10.1101/2021.07.05.21260026; this version posted July 7, 2021. The copyright holder for this preprint

(which was not certified by peer review) is the author/funder, who has granted medRxiv a license to display the preprint in perpetuity. It is made available under a CC-BY-NC-ND 4.0 International license.

\section{INTRODUCTION}

Multiple studies have described increased mortality in Black and Asian people with COVID-19 in the UK. ${ }^{1-5}$ In many of these reports, Black people were at equal or greater risk of death than Asian people. These studies have included large analyses of hospitalised patients and analyses of COVID-19 associated deaths within large sets of primary care records. ${ }^{5}$ However due to geographic variation, representation of ethnic minority groups in many of these datasets were small and this has potential to bias analyses. Our initial report of almost 2000 COVID-19 associated emergency admissions in the first wave of COVID-19 was distinguished by inclusion of a significant number of patients drawn from the same geographic region (east London) where more than fifty percent of patients came from ethnically diverse backgrounds. ${ }^{6}$

In the winter of 2020, the UK experienced a devastating second wave of COVID-19 which compared to the first, had greater impact on healthcare services and higher number of deaths. ${ }^{7,8}$ Since the first wave, there have been societal behavioural change, improved COVID-19 treatments, and better algorithms of care, which have the potential to both mitigate or magnify ethnic inequalities in adverse outcomes associated with COVID-19. Furthermore, there have been directed initiatives aimed at identifying the driving factors behind these disparities. ${ }^{9}$ However, it is unclear if these ethnic inequalities persisted over time. In the UK, east London was at the epicentre of both waves of COVID-19. In the second wave, across four acute NHS hospitals in this region, we continued to treat high acuity patients and centralised surge critical care capacity on one site in a purpose-built ICU (The Queen Elizabeth Unit). This large, regional dataset afforded extensive analyses of COVID-19 patients to further characterise the risk factors within different ethnic groups of hospitalised COVID-19 patients. In this study, we aimed to determine if ethnic disparities during the first wave of COVID-19 have been mitigated during the second wave and the long-term survival of the first wave patients after one year. 


\section{METHODS}

We considered all adults (age $\geq 16$ years) with confirmed SARS-CoV-2 infection admitted as emergencies to one of the four acute hospitals within Barts Health NHS Trust between $1^{\text {st }}$ September 2020 and $17^{\text {th }}$ February 2021. The first emergency admission encompassing the first positive SARS-CoV-2 test on real-time polymerase chain reaction (PCR) test, or the first emergency admission within two weeks of positive outpatient testing was defined as the index admission. Community diagnoses without an associated emergency hospital admission were excluded. Patients with unknown or undisclosed ethnicity status were collected for comparison but excluded from primary statistical analyses. In addition, we conducted extended follow-up of the 1996 SARS-CoV-2 hospital admissions up to $20^{\text {th }}$ May 2020, presented previously, to assess one-year survival. ${ }^{6}$ Finally, for patients resident in the London Boroughs of Tower Hamlets, Waltham Forest, and Newham, we assessed the relative frequency of SARS-CoV-2 associated acute hospital admissions, compared to the age and ethnicity distribution of this local population in the 2011 UK census.

\section{Data sources}

Clinical and demographic data, blood results, and coding data from current and prior clinical encounters, were collated from the Barts Health Cerner Millennium Electronic Medical Record (EMR) data warehouse by members of the direct clinical care team. Mortality data was available to $25^{\text {th }}$ May 2021, enabling 90-day follow-up. Population level analyses of age, sex, and ethnicity distributions in the London boroughs of Tower Hamlets, Newham,, and Waltham Forest were taken from the 2011 census provided by Official Labour Market Statistics (nomis). ${ }^{10}$

\section{Definition of key variables}

Ethnicity was defined using the NHS ethnic category codes and based on five high-level groups: White, Asian or Asian British, Black or Black British, Mixed, and Other. In the NHS categorisation, the Asian group is predominantly South Asian (Indian, Bangladeshi, Pakistani) with Chinese ethnicity assigned to the Other group, while in the 2011 census Chinese is assigned to the Asian higher-level group, for consistency the NHS high-level group definitions were applied to the census data. Due to small numbers in the Mixed group, the Mixed and Other categories were merged in multivariable modelling to preserve statistical power. Relative measures of socioeconomic deprivation were assessed using the English Indices of Deprivation 2020 by matching patient postcode to the national Index of Multiple Deprivation (IMD) using the Office of National Statistics Postcode Directory. ${ }^{11}$ Due to the level of deprivation of the majority of our study population, relative deprivation in this study was analysed based on quintiles of IMD within our study population. Baseline comorbid diseases, Charlson Comorbidity Index (CCI), and Hospital Frailty Risk Score (HFRS) were identified by mapping to ICD-10 coding. ${ }^{12}$ Body Mass Index (BMI) was calculated by height and weight measurements taken at or during the immediately preceding admission episode. Rockwood Clinical Frailty Scoring (RFS) was assessed by the admitting medical team. ${ }^{13}$ Full definitions are detailed in supplementary materials.

\section{Outcomes}

Primary outcome was 30-day mortality from time of index COVID-19 hospital admission. Secondary endpoints were 90-day mortality and need for ICU admission defined by need for advanced respiratory support alone or basic respiratory support together with support for at least two organ systems.

\section{Statistical analyses}

Our analysis plan followed our first wave COVID study. ${ }^{14}$ Baseline characteristics are presented as mean and SD, median and IQR, or number and percentage, as appropriate. We compared proportions using Pearson's $\chi^{2}$ test or Fisher's exact test and continuous variables using Wilcoxon rank-sum test and Kruskal-Wallis rank sum test, as appropriate. Time-to-event analysis was undertaken with survivors censored at 30 or 90 days or at time of maximal follow-up. Prolonged follow-up of our first wave cohort was examined over 270 days. Cox-proportional hazards models was used to assess survival adjusted for age, sex, and predefined risk factors associated with adverse outcomes in COVID-19: IMD quintile, smoking status, obesity, diabetes, hypertension, and chronic kidney disease (CKD). Additional multivariable models were also carried out as sensitivity analyses using aggregate CCI as a measure of total comorbid disease burden, and HFRS at hospital admission. The proportional hazard assumption was assessed by inspection of scaled Schoenfeld residual plots and investigated by stratification if required. ${ }^{15}$ Factors associated with ICU admission were examined using logistic regression. Effect measures are presented as Hazard or Odds ratios with 95\% CI. All analyses were performed using R v4.0.2 (R Core Team 2020).

\section{Rates of admission}

Barts Health hospitals primarily serve three London Boroughs: Tower Hamlets, Newham, and Waltham Forest. Patients residing within these areas were identified by postcode and age-adjusted rates of admission per 100,000 
medRxiv preprint doi: https://doi.org/10.1101/2021.07.05.21260026; this version posted July 7, 2021. The copyright holder for this preprint

(which was not certified by peer review) is the author/funder, who has granted medRxiv a license to display the preprint in perpetuity. It is made available under a CC-BY-NC-ND 4.0 International license.

of the local population within each ethnic group were derived for COVID-19 first and second wave admissions by standardisation to the Revised European Standard Population. ${ }^{16}$ For comparison to non-COVID admissions, we also calculated age-standardised admissions per 100,000 for each ethnic group in all Barts Health emergency admissions residing in these three boroughs during the years 2013-18 inclusive. Overall rates are presented relative to that of the White ethnic group for comparison of relative admission rates between first and second waves and the pre-COVID baseline. 


\section{RESULTS}

A total of 5533 patients were identified (Fig S1). The majority of admissions occurred during December 2020 and January 2021 (Fig S2). Three-quarters of patients were classified as being in the four most deprived socioeconomic deciles in England (Table S1). Only around one third were White $(\mathrm{n}=1805,32.6 \%)$. Ethnically diverse groups comprised around $70 \%$ of the cohort: Asian or Asian British $(n=1983,35.8 \%)$, Black or Black British $(\mathrm{n}=634,11.4 \%)$, Mixed/Other $(\mathrm{n}=433,7.8 \%)$ and unknown or undisclosed $(\mathrm{n}=678,12.2 \%)$.

\section{Population characteristics}

Baseline characteristics, interventions, and outcomes across ethnic groups are shown in Table 1. Black and Asian ethnicity patients were significantly younger with a median age of 58 years (Asian) and 60 years (Black), compared with 70 years in the White group $(\mathrm{p}<0.001)$. Comorbidity data were available in $5518(99.7 \%)$ of patients and burden of comorbid disease varied between ethnic groups in prevalence, type, and age distribution. Diabetes and CKD were more prevalent at an earlier age in Asian and Black patients, frailty and dementia were more prevalent in older White patients (Table 1, Table S2). UK National Early Warning Score within the first day of admission was clinically similar between groups with a 0.5 difference in mean scores between the highest and lowest groups (2.8 in Mixed/Other, 2.3 in Black). Around one in five patients developed early acute kidney injury (AKI) within seven days of hospital admission, rates of AKI were highest in the Black group $(25 \%)$. Peak Creactive protein (CRP) during admission did not differ significantly between groups however peak D-dimer was higher in the Black population (median $2.23 \mathrm{mg} / \mathrm{L}$ ) compared with other ethnicities (median $1.21 \mathrm{mg} / \mathrm{L} \mathrm{Asian,}$ $1.54 \mathrm{mg} / \mathrm{L}$ White).

\section{Age- and sex-adjusted survival}

Overall raw 30 -day mortality was $17.6 \%$, ranging from $20 \%$ in the White group to $12 \%$ in the Mixed/Other group. We considered 4855 patients with documented ethnicity in the primary outcome analysis, of these $46(0.95 \%)$ had incomplete data and were excluded from multivariable survival analysis. After adjustment for between-group differences in age, sex, presence of diabetes, CKD, hypertension, smoking history, obesity, and socioeconomic deprivation, patients with Asian ethnicity were at significantly higher risk of death within 30 days compared to White patients (HR 1.47 [1.24-1.73]). No association with increased risk of death was observed in the Black or Mixed/Other groups (Table 2, Fig 1a). There was no statistical evidence for violation of the proportional-hazards assumption. Increased rate of death in the Asian group was also demonstrated in analyses including total CCI (HR 1.47 [1.26-1.72]) or HFRS (HR 1.62 [1.38-1.89]) rather than specific comorbidities (Table 2, Figs S3-4). This effect was persistent when the initial analysis was extended to 90-day mortality (HR for Asian ethnicity 1.41 [1.22-1.64]) (Table 2, Figs $1 \mathrm{~b}$ and 2).

\section{ICU admission}

ICU admission occurred in $11.9 \%$ of cases and was lowest in the White group (9.4\%) and highest in the Asian $(13 \%)$ and Mixed/Other groups (14\%) (Table 1). In multivariable analysis excluding unknown ethnicity and unknown comorbidity (n=4809), Asian (OR 1.38 [1.10-1.73]) and Mixed/Other (OR 1.53 [1.11-2.11]) ethnicities were associated with increased age-, sex-, and comorbidity-adjusted risk of ICU admission (Table 2, Fig S5).

\section{Extended follow up of first wave patients}

All 1996 patients admitted during the first wave were re-analysed 12 months after admission. Overall, 365-day mortality was $32.9 \%$ with only a further $2.4 \%$ of the initial population dying between days 90 and 365 . Age-, sex, and comorbidity-adjusted survival analysis in 1722 patients with known ethnicity and comorbidity data is shown in Fig 3. In this analysis adjusted risk of death associated with Asian ethnicity remained significant (HR 1.38 [1.12-1.71]) (Table 2, Fig S6). However, the trend we previously observed for increased mortality in Black patients was not sustained over time. In this analysis, ethnicity showed significant violation of the proportionalhazards assumption. Remodelling with stratification by ethnicity (Fig 3) suggested sustained, proportional increases in risk of death in Asian patients, but that the initially higher rate of death in Black patients was attenuated over time so that predicted survival at one-year was similar to White patients, after controlling for age, sex and other risk factors.

\section{Comparison of second and first waves}

Overall, in comparison with the first wave data, significantly more patients were included (5533 vs 1996). Median age was lower in the second wave in White (70 vs 73, $\mathrm{p}<0.001)$, Black (60 vs 64, $\mathrm{p}<0.001)$ but not Asian ( 58 vs $59, \mathrm{p}=0.21)$ groups. In the second wave, a larger proportion of admissions were in Asian patients $(35.7 \% \mathrm{vs}$. $27.0 \%, \mathrm{p}<0.001)$ and a smaller proportion in Black patients $(11.4 \% \mathrm{vs} 17.0 \%, \mathrm{p}<0.001)$. While the proportion of White patients in the second wave also decreased, this change was relatively slight $(32.6 \% \mathrm{vs} 35.8 \%, \mathrm{p}=0.04)$. Overall raw 30-day mortality was $17.6 \%$ compared to $27.4 \%$ in the first wave cohort $(\mathrm{p}<0.001)$. Furthermore, predicted age-, sex-, and comorbidity-adjusted survival improved in all groups: predicted 30-day mortality in a 
medRxiv preprint doi: https://doi.org/10.1101/2021.07.05.21260026; this version posted July 7,2021 . The copyright holder for this preprint

(which was not certified by peer review) is the author/funder, who has granted medRxiv a license to display the preprint in perpetuity. It is made available under a CC-BY-NC-ND 4.0 International license.

65-year-old male of White ethnicity without diabetes, CKD, hypertension, obesity, smoking history, and median IMD was $9.0 \%(6.9-11.1 \%)$ in the second wave model, compared to $16.4 \%(11.8-20.9 \%)$ in the first wave model (Figs 2, 3). There was a similar difference across ethnic groups, for a similar patient of Asian ethnicity, predicted 30 -day mortality was $12.9 \%(10.0-15.7 \%)$ in the second wave versus $23.2 \%(16.9-28.9 \%)$ in the first (Figs 2,3$)$. Other notable changes included lower peak CRPs in the second wave across all groups and lower rates of ICU admission both overall (11.9 vs $15.9 \%, \mathrm{p}<0.001)$ and within ethnic groups.

\section{Admission rates}

Admissions within each ethnic group by age group and the local population distribution are shown in Tables S36 and Figure 4. Relative to the White population, local Asian and Black populations experienced between two to four-fold higher age-standardised rates of hospital admissions during the COVID-19 first and second waves, with a 4.07 (3.77-4.39) times higher rate in Asian patients in the second wave (Table 3). By comparison during 201318, age-standardised rates of emergency admissions in local Black and Asian populations were only 10-30\% greater than in White local-residents. Finally, up to $10 \%$ of hospital admissions were recorded as of unknown ethnicity, a categorisation not used in the 2011 UK census. 


\section{DISCUSSION}

The principal finding of this study was that amongst 5533 patients hospitalised with COVID-19 in the ethnically diverse area of east London during the second wave, there remained important ethnic disparities in patient outcomes. In the second wave, the proportion of patient-admissions of Asian ethnicity increased, most markedly in the younger age groups. In the second wave the increased risk of death amongst Asian patients seen in the first wave persisted, whilst patients of Black ethnicity had comparable outcomes to White patients in the second wave. Similarly, the increased risk of death in Asian patients admitted during the first wave continued during prolonged follow-up whereas Black patients showed no longer-term risk compared to White inpatients.

We considered differential rates of admission between ethnic groups as an additional contributor to ethnic imbalances in the impact of COVID-19. By comparing age and ethnicity from inpatients drawn from three boroughs in east London with the local population, we were able to demonstrate that rates of admission were 24-fold higher in Black and Asian compared to White populations with a similar age distribution. This effect particularly prominent in the Asian population in the second wave and the Black population in the first. Importantly, these increased rates of admission in ethnic minority groups were substantially higher than seen in emergency admissions to Barts Health hospitals from the same local community prior to COVID. Notably, in contrast to our findings in COVID-19, in the pre-COVID cohort Black and Asian ethnicities had lower age-, sex, and comorbidity-adjusted risk of death compared to white emergency admissions (manuscript under review), similar to findings for non-COVID death reported from the OPENSafely platform. ${ }^{17}$ Furthermore, a significant number of admissions with unknown ethnicity and a small excess of patients classified as of Other ethnicity are likely to reflect a substantial number of additional patients with non-White background, if anything increasing the excess rate of admissions in minority categories.

Compared to the first wave, mortality was over one third lower across all ethnic groups, even after adjustment for age and comorbidity differences. This may indicate improvements in specific treatments, ${ }^{18,19}$ including routine early use of corticosteroids, ${ }^{20}$ and in processes of care, ${ }^{21}$ including the development of purpose built a 150-bed COVID-ICU at the Royal London Hospital. ${ }^{22}$ In addition, the total patient population appeared less acutely unwell with fewer ICU admissions, lower levels of AKI, and lower peak markers of inflammation. This could reflect treatment changes both in and before hospitalisation or a change in disease profile over time. However, despite apparent improvements in outcomes overall excess risk of death in patients of Asian background persisted in both the second wave and prolonged follow-up of the first. In contrast, early risk of death in Black patients in the first wave was not sustained over prolonged follow-up, and in the second wave, risk of death following hospital admission associated with Black ethnicity did not differ significantly to White ethnicity. This finding is in line with other studies examining the first wave data in hospitalised patients across the $\mathrm{UK}^{23}$ and early second wave data examining COVID-19 deaths in a large primary care dataset. ${ }^{24}$ Importantly, our results suggest that differential rates of hospitalisation rather than hospital outcomes themselves may be the strongest ethnic inequality driving adverse outcomes associated with COVID-19, particularly for Black patients. This suggests that COVID acquisition, rather than delayed presentation or response to treatment in hospital is one of the leading drivers of excess mortality in these populations. Those of South Asian background do appear doubly affected experiencing an almost 4-fold higher age-matched rate of hospitalisation as well as a $30-40 \%$ increased chance of death once hospitalised compared to similar White patients. Importantly, these differences have persisted despite improvement in treatments, processes of care, and COVID-19 outcomes in general.

\section{Reasons for ethnicity inequality in COVID outcomes}

Disparities in health outcomes and mortality rates between people of different ethnicities has been the subject of intense public and medical scrutiny and debate. Numerous potential drivers for these inequalities have been suggested including differences in socioeconomic status, occupational exposure, housing density, access to home working, multi-generational living, engagement with and access to healthcare services, incidence and severity of comorbid disease. ${ }^{25,26}$ Furthermore, the effects of racism and structural discrimination are an important underpinning consideration. ${ }^{27}$ Although we have attempted to account for some of these factors such as comorbidity differences, presence or absence of conditions such as diabetes of hypertension may fail to account for differences in disease severity and duration of exposure between ethnic groups. Similarly, postcode-based assessment of deprivation may fail to account for differences in the relative poverty between ethnic groups living in the same community. Notably, this study population is drawn from a community with a relatively high level of deprivation with comparatively little variation, which may account for a lack of association between deprivation and survival in our analysis. Consequently, the White comparator population in this study may represent a group with worse underlying health than the general UK population. 
medRxiv preprint doi: https://doi.org/10.1101/2021.07.05.21260026; this version posted July 7, 2021. The copyright holder for this preprint

(which was not certified by peer review) is the author/funder, who has granted medRxiv a license to display the preprint in perpetuity. It is made available under a CC-BY-NC-ND 4.0 International license.

\section{Strengths and limitations}

This analysis supports the findings of several published and pre-printed analyses examining ethnicity and COVID19 outcomes in the UK but is distinguished by the large representation of ethnic minority groups and large absolute numbers of these patients drawn from a single geographic region and treated within the same hospital system. Importantly previous analyses are drawn from large populations which may poorly represent the most ethnically diverse areas of the UK. The OPENSAFELY dataset was only $6 \%$ Asian and $2 \%$ Black in the first wave, ${ }^{3}$ and $7.2 \%$ Asian 1\% Black in the second wave, ${ }^{28}$ the Second Generation Surveillance System (SGSS)/COVID-19 Hospitalization in England Surveillance System (CHESS) dataset 8.4\% Asian 3.8\% Black, ${ }^{29}$ and the ISARIC dataset $4.5 \%$ South Asian and 3.6\% Black. ${ }^{23}$ In terms of absolute patients numbers, this study thus represents one of the largest descriptor of outcomes in minority ethnic patients with COVID-19 (Table S7) and is strengthened by comparison to a White population drawn from the same location experiencing the same treatment, eliminating many of the geographic biases present within larger studies with poorer minority ethnic representation. Our analyses are strengthened by adherence to a prespecified analysis plan, inclusion of a range of baseline, comorbidity, and COVID-19 risk factors in multivariable modelling, and sensitivity tests using different measures of comorbidity. However as with all observational studies, not all potential contributing risk factors could be assessed, including other measures of baseline health status such as nutritional or lifestyle influences. We were also unable to compare the effect of the differing viral strains in the first and second wave. Other limitations include not being able to include suspected but not proven COVID-19 cases or community cases not requiring hospital admission. In addition, contextual factors such as household composition and occupation could not be assessed. Currently, ethnic categorisations used in healthcare do not reflect the vast heterogeneity within each aggregated ethnic category. There may be specific differences in presentation and outcomes particularly across Black people (Black African versus Black Caribbean) and Asian people (Bangladeshi/Pakistani versus Indian). Similarly, using a composite measure to assess socioeconomic deprivation limits the ability to evaluate varying effects of sub-domains. Finally, as previously discussed, our study population has a particularly high relative level of socioeconomic deprivation overall and the variation in patterns of deprivation between and within ethnic groups may differ with other study cohorts.

\section{Conclusion}

Despite improvement in overall outcomes, better treatments, and processes of care, Asian and Black ethnic groups continue to have an increased hospital admission and death in hospital associated with COVID-19. Our findings suggest that COVID acquisition rather than delayed presentation or response to treatment in hospital may be one of the leading drivers of excess mortality in the ethnic minority populations in east London. This confirms the need to understand and contextualise structural and socioeconomic factors that drive these outcomes. To achieve this, qualitative data will need to be aligned with insight from community-based qualitative research exploring the lived realities of minority ethnic communities in order to inform the implementation of impactful communitylevel interventions. 
medRxiv preprint doi: https://doi.org/10.1101/2021.07.05.21260026; this version posted July 7,2021 . The copyright holder for this preprint

(which was not certified by peer review) is the author/funder, who has granted medRxiv a license to display the preprint in perpetuity.

It is made available under a CC-BY-NC-ND 4.0 International license.

\section{Contributions}

Study Concept and Design

Ethics application and Approvals

Study protocol and analysis plan

Data Extraction

Data Analysis

Critical review of finding

Manuscript writing

Review of final submission
YIW VJA CMO RD RMP ZP JRP

VJA JRP

YIW JRP

YIW JRP

YIW JRP

All authors

YIW JRP

All authors

\section{Ethics approval}

This study was approved by NHS England Health Research Authority and Yorkshire \& The Humber - Bradford Leeds Research Ethics Committee and approved as anonymised analysis of routinely collected patient data without need for direct consent (Ethics reference 20/YH/0159).

\section{Funding}

This research received no specific grant from any funding agency in the public, commercial or not-for-profit sectors.

\section{Declarations of interest}

All authors declare no other competing interests.

\section{Data sharing}

The statistical analysis plan can be accessed online. The authors will be happy to consider additional analyses of the anonymised dataset on request. The need for stringent measures to prevent re-identification of individuals within a discrete geographical location and limited time-period however preclude sharing of patient level dataset in a GDPR compliant form. 


\section{References}

1. Aldridge RW, Lewer D, Katikireddi SV, et al. Black, Asian and Minority Ethnic groups in England are at increased risk of death from COVID-19: indirect standardisation of NHS mortality data. Wellcome Open Research 2020; 5: 88 .

2. Niedzwiedz CL, O'Donnell CA, Jani BD, et al. Ethnic and socioeconomic differences in SARS-CoV-2 infection: prospective cohort study using UK Biobank. BMC Med 2020; 18(1): 160.

3. Williamson EJ, Walker AJ, Bhaskaran K, et al. Factors associated with COVID-19-related death using OpenSAFELY. Nature 2020; 584(7821): 430-6.

4. Raisi-Estabragh Z, McCracken C, Bethell MS, et al. Greater risk of severe COVID-19 in Black, Asian and Minority Ethnic populations is not explained by cardiometabolic, socioeconomic or behavioural factors, or by 25(OH)-vitamin D status: study of 1326 cases from the UK Biobank. J Public Health (Oxf) 2020; 42(3): 45160 .

5. Sze S, Pan D, Nevill CR, et al. Ethnicity and clinical outcomes in COVID-19: A systematic review and meta-analysis. EClinicalMedicine 2020; 29: 100630.

6. Apea VJ, Wan YI, Dhairyawan R, et al. Ethnicity and outcomes in patients hospitalised with COVID-19 infection in East London: an observational cohort study. BMJ Open 2021; 11(1): e 042140.

7. Office of National Statistics. Deaths involving COVID-19, England and Wales, provisional: week ending 26 March 2021 [Online]. 8 April 2021 [Cited: 23 May 2020]. https://www.ons.gov.uk/releases/deathsregisteredweeklyinenglandandwalesprovisionalweekending26march202 1 (accessed 12 April 2021).

8. Intensive Care National Audit \& Research Centre (ICNARC). ICNARC report on COVID-19 in critical care: England, Wales and Northern Ireland 26 March 2021. https://www.icnarc.org/OurAudit/Audits/Cmp/Reports (accessed 12 April 2021).

9. National Institute of Health Research (NIHR). https://www.nihr.ac.uk/news/multimillion-investment-innew-research-projects-to-investigate-higher-covid-19-risk-among-certain-ethnic-groups/25333.

https://www.nihr.ac.uk/news/multimillion-investment-in-new-research-projects-to-investigate-higher-covid-19risk-among-certain-ethnic-groups/25333. (accessed 12 April 2021).

10. Official labour market statistics. LC2101EW - Ethnic group by sex by age. https://www.nomisweb.co.uk/query/construct/summary.asp?mode=construct\&version=0\&dataset=801 (accessed 20 March 2021).

11. Office for National Statistics (ONS). English indices of deprivation 2019. https://www.gov.uk/government/statistics/english-indices-of-deprivation-2019. (accessed 20 March 2021).

12. Gilbert T, Neuburger J, Kraindler J, et al. Development and validation of a Hospital Frailty Risk Score focusing on older people in acute care settings using electronic hospital records: an observational study. Lancet 2018; 391(10132): 1775-82.

13. Rockwood K, Song X, MacKnight C, et al. A global clinical measure of fitness and frailty in elderly people. CMAJ 2005; 173(5): 489-95.

14. Wan Y, Apea V, Dhairyawan R, Orkin C, Pearse R, Prowle J. ETHICAL: Ethnic Disparities In COVID19 Admissions in east London (Statistical analysis plan). 2020.

15. Stensrud MJ, Hernán MA. Why Test for Proportional Hazards? JAMA 2020; 323(14): 1401.

16. Pace M. LG, Glickman M., Zupanič T. Revision of the European Standard Population. 2013. https://ec.europa.eu/eurostat/documents/3859598/5926869/KS-RA-13-028-EN.PDF/e713fa79-1add-44e8-b23d5e8fa09b3f8f (accessed 20 March 2021).

17. Bhaskaran K, Bacon SCJ, Evans SJW, et al. Factors associated with deaths due to COVID-19 versus other causes: population-based cohort analysis of UK primary care data and linked national death registrations within the OpenSAFELY platform. medRxiv 2021: 2021.01.15.21249756.

18. Gattinoni L, Chiumello D, Caironi P, et al. COVID-19 pneumonia: different respiratory treatments for different phenotypes? Intensive Care Med 2020; 46(6): 1099-102.

19. Moores LK, Tritschler T, Brosnahan S, et al. Prevention, Diagnosis, and Treatment of VTE in Patients With Coronavirus Disease 2019: CHEST Guideline and Expert Panel Report. Chest 2020; 158(3): 1143-63.

20. Horby P, Lim WS, Emberson JR, et al. Dexamethasone in Hospitalized Patients with Covid-19. N Engl $J$ Med 2021; 384(8): 693-704.

21. Yousuf B, Sujatha KS, Alfoudri H, Mansurov V. Transport of critically ill COVID-19 patients. Intensive Care Med 2020; 46(8): 1663-4.

22. Watts C. The Queen Elizabeth unit at The Royal London hospital. 2021.

23. Harrison EMaD, Annemarie B. and Barr, Benjamin and Buchan, Iain and Carson, Gail and Drake, Tom M. and Dunning, Jake and Fairfield, Cameron J. and Gamble, Carrol and Green, Christopher A. and Griffiths, Chris and Halpin, Sophie and Hardwick, Hayley E. and Ho, Antonia and Holden, Karl A. and Hollinghurst, Joe and Horby, Peter W. and Jackson, Clare and Katikireddi, Srinivasa Vittal and Knight, Stephen and Lyons, Ronan 
medRxiv preprint doi: https://doi.org/10.1101/2021.07.05.21260026; this version posted July 7,2021 . The copyright holder for this preprint

(which was not certified by peer review) is the author/funder, who has granted medRxiv a license to display the preprint in perpetuity. It is made available under a CC-BY-NC-ND 4.0 International license.

and MacMahon, James and Mclean, Kenneth A. and Merson, Laura and Murphy, Derek and Nguyen-Van-Tam, Jonathan S. and Norman, Lisa and Olliaro, Piero L. and Pareek, Manish and Piroddi, Roberta and Pius, Riinu and Read, Jonathan M. and Russell, Clark D. and Sattar, Naveed and Shaw, Catherine A. and Sheikh, Aziz and Sinha, Ian P. and Swann, Olivia and Taylor-Robinson, David and Thomas, Daniel and Turtle, Lance and Openshaw, Peter JM and Baillie, J. Kenneth and Semple, Malcolm G. and Investigators, ISARIC4C. Ethnicity and Outcomes from COVID-19: The ISARIC CCP-UK Prospective Observational Cohort Study of Hospitalised Patients.: Available at SSRN: $\quad$ https://ssrn.com/abstract=3618215 or $\quad$ http://dx.doi.org/10.2139/ssrn.3618215; 2020. 24. Bhaskaran K, Mathur R, Rentsch CT, et al. Short report: Ethnicity and COVID-19 death in the early part of the COVID-19 second wave in England: an analysis of OpenSAFELY data from 1st September to 9th November 2020. medRxiv 2021: 2021.02.02.21250989.

25. SAGE publishing group. Drivers of the higher COVID-19 incidence, morbidity and mortality among

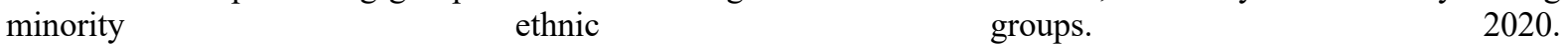
https://assets.publishing.service.gov.uk/government/uploads/system/uploads/attachment data/file/925135/S077 8 Drivers of the higher COVID19 incidence morbidity and mortality among minority ethnic groups.pdf (accessed 12 April 2021). 26. SAGE publishing group. COVID-19 Ethnicity subgroup: Interpreting differential health outcomes among minority ethnic groups in wave 1 and 2, 24 March 2021. 2021. https://www.gov.uk/government/publications/covid-19-ethnicity-subgroup-interpreting-differential-healthoutcomes-among-minority-ethnic-groups-in-wave-1-and-2-24-march-2021 (accessed 12 April 2021). 27. Iacobucci G. What did the Commission on Race and Ethnic Disparities say on health? BMJ 2021; 373: n943.

28. Mathur R, Rentsch CT, Morton CE, et al. Ethnic differences in SARS-CoV-2 infection and COVID-19related hospitalisation, intensive care unit admission, and death in 17 million adults in England: an observational cohort study using the OpenSAFELY platform. Lancet 2021; 397(10286): 1711-24.

29. Public Health England. Disparities in the risk and outcomes of COVID-19. 2020. https:/assets.publishing.service.gov.uk/government/uploads/system/uploads/attachment data/file/908434/Dispa rities in the risk and outcomes of COVID August 2020 update.pdf (accessed 12 April 2021). 
medRxiv preprint doi: https://doi.org/10.1101/2021.07.05.21260026; this version posted July 7, 2021. The copyright holder for this preprint

(which was not certified by peer review) is the author/funder, who has granted medRxiv a license to display the preprint in perpetuity.

It is made available under a CC-BY-NC-ND 4.0 International license.

\section{Tables}

Table 1: Characteristics of 5533 patients with COVID-19 associated first hospital admissions during second pandemic wave between $1 / 9 / 20$ and $17 / 2 / 21$.

Table 2: Multivariable modelling (PH: Proportional Hazards, LR: Logistic Regression).

Table 3: Hospital admission rates per 100,000 of the age-standardized local population by ethnic group (based on European standard population for ages 15 to $85+$ ). 
medRxiv preprint doi: https://doi.org/10.1101/2021.07.05.21260026; this version posted July 7,2021 . The copyright holder for this preprint (which was not certified by peer review) is the author/funder, who has granted medRxiv a license to display the preprint in perpetuity. It is made available under a CC-BY-NC-ND 4.0 International license .

Table 1: Characteristics of 5533 patients with COVID-19 associated first hospital admissions during second pandemic wave between $1 / 9 / 20$ and 17/2/21.

\begin{tabular}{|c|c|c|c|c|c|c|c|}
\hline & $\mathbf{n}$ & $\begin{array}{l}\text { White } \\
1,805\end{array}$ & $\begin{array}{c}\text { Black } \\
634\end{array}$ & $\begin{array}{l}\text { Asian } \\
\mathbf{1 , 9 8 3}\end{array}$ & $\begin{array}{c}\text { Other } \\
\text { /Mixed } \\
433\end{array}$ & $\begin{array}{c}\text { Not known } \\
678\end{array}$ & p-value \\
\hline Female & 5,533 & $859(48 \%)$ & $329(52 \%)$ & $903(46 \%)$ & $195(45 \%)$ & $303(45 \%)$ & 0.039 \\
\hline Smoking & 5,518 & $340(19 \%)$ & $87(14 \%)$ & $200(10 \%)$ & $50(12 \%)$ & $57(8.4 \%)$ & $<0.001$ \\
\hline IMD pop. quintiles & 5,490 & & & & & & $<0.001$ \\
\hline 1 & & $309(17 \%)$ & $184(29 \%)$ & $390(20 \%)$ & $98(23 \%)$ & $121(18 \%)$ & \\
\hline 2 & & $313(17 \%)$ & $124(20 \%)$ & $408(21 \%)$ & $91(21 \%)$ & $149(22 \%)$ & \\
\hline 3 & & $286(16 \%)$ & $120(19 \%)$ & $479(24 \%)$ & $76(18 \%)$ & $145(22 \%)$ & \\
\hline 4 & & $320(18 \%)$ & $132(21 \%)$ & $427(22 \%)$ & $90(21 \%)$ & $134(20 \%)$ & \\
\hline 5 & & $563(31 \%)$ & $69(11 \%)$ & $269(14 \%)$ & $72(17 \%)$ & $121(18 \%)$ & \\
\hline Unknown & & 14 & 5 & 10 & 6 & 8 & \\
\hline$B M I \mathrm{~kg} / \mathrm{m}^{2}$ & 4,383 & $\begin{array}{c}27 \\
(23,32)\end{array}$ & $\begin{array}{c}28 \\
(24,33)\end{array}$ & $\begin{array}{c}27 \\
(24,31)\end{array}$ & $\begin{array}{c}28 \\
(24,32)\end{array}$ & $\begin{array}{c}27 \\
(24,32)\end{array}$ & 0.003 \\
\hline Unknown & & 313 & 123 & 441 & 106 & 167 & \\
\hline $\begin{array}{l}\text { BMI }>30 \text { or } \\
\text { Obesity Code }\end{array}$ & 5,530 & $521(29 \%)$ & $223(35 \%)$ & $511(26 \%)$ & $128(30 \%)$ & $188(28 \%)$ & $<0.001$ \\
\hline Unknown & & 1 & 0 & 1 & 0 & 1 & \\
\hline$M I$ & & $232(13 \%)$ & $36(5.7 \%)$ & $256(13 \%)$ & $27(6.2 \%)$ & $29(4.3 \%)$ & $<0.001$ \\
\hline $\mathrm{CHF}$ & & $362(20 \%)$ & $102(16 \%)$ & $286(14 \%)$ & $47(11 \%)$ & $60(8.9 \%)$ & $<0.001$ \\
\hline$P V D$ & & $266(15 \%)$ & $69(11 \%)$ & $134(6.8 \%)$ & $34(7.9 \%)$ & $40(5.9 \%)$ & $<0.001$ \\
\hline CEVD & & $364(20 \%)$ & $122(19 \%)$ & $273(14 \%)$ & $46(11 \%)$ & $463(9.3 \%)$ & $<0.001$ \\
\hline Dementia & & $202(11 \%)$ & $56(8.9 \%)$ & $107(5.4 \%)$ & $18(4.2 \%)$ & $26(3.9 \%)$ & $<0.001$ \\
\hline$C O P D$ & & $549(30 \%)$ & $115(18 \%)$ & $525(27 \%)$ & $86(20 \%)$ & $109(16 \%)$ & \\
\hline$D M$ & & $467(26 \%)$ & $273(43 \%)$ & $911(46 \%)$ & $117(27 \%)$ & $184(27 \%)$ & $<0.001$ \\
\hline$H T N$ & & $1009(56 \%)$ & $412(65 \%)$ & $1,085(55 \%)$ & $195(45 \%)$ & $276(41 \%)$ & $<0.001$ \\
\hline$C K D$ & & $418(23 \%)$ & $185(29 \%)$ & $426(22 \%)$ & $48(11 \%)$ & $76(11 \%)$ & $<0.001$ \\
\hline$C K D-5 D$ & & $35(1.9 \%)$ & $56(8.8 \%)$ & $103(5.2 \%)$ & $11(2.5 \%)$ & $18(2.7 \%)$ & $<0.001$ \\
\hline Liver Disease & & $225(12 \%)$ & $76(12 \%)$ & $190(9.6 \%)$ & $41(9.5 \%)$ & $51(7.6 \%)$ & 0.002 \\
\hline Cancer & & $210(12 \%)$ & $56(8.9 \%)$ & $95(4.8 \%)$ & $19(4.4 \%)$ & $27(4.0 \%)$ & $<0.001$ \\
\hline Metastasis & & $81(4.5 \%)$ & $20(3.2 \%)$ & $23(1.2 \%)$ & $8(1.9 \%)$ & $10(1.5 \%)$ & $<0.001$ \\
\hline Charlson Index & 5,518 & & & & & & $<0.001$ \\
\hline 0 & & $482(27 \%)$ & $156(25 \%)$ & $620(31 \%)$ & $192(44 \%)$ & $299(44 \%)$ & \\
\hline $1-2$ & & $576(32 \%)$ & $217(34 \%)$ & $656(33 \%)$ & $145(34 \%)$ & $246(36 \%)$ & \\
\hline
\end{tabular}


medRxiv preprint doi: https://doi.org/10.1101/2021.07.05.21260026; this version posted July 7,2021 . The copyright holder for this preprint

(which was not certified by peer review) is the author/funder, who has granted medRxiv a license to display the preprint in perpetuity.

It is made available under a CC-BY-NC-ND 4.0 International license .

\begin{tabular}{|c|c|c|c|c|c|c|c|}
\hline $3-4$ & & $338(19 \%)$ & $102(16 \%)$ & $327(17 \%)$ & $51(12 \%)$ & $82(12 \%)$ & \\
\hline$>=5$ & & $406(23 \%)$ & $156(25 \%)$ & $376(19 \%)$ & $44(10 \%)$ & $49(7.3 \%)$ & \\
\hline Unknown & & 3 & 3 & 4 & 1 & 4 & \\
\hline Baseline eGFR & 2,840 & $\begin{array}{c}70 \\
(52,87)\end{array}$ & $\begin{array}{c}85 \\
(61,108)\end{array}$ & $\begin{array}{c}80 \\
(59,98)\end{array}$ & $\begin{array}{c}83 \\
(65,98)\end{array}$ & $\begin{array}{c}85 \\
(66,100)\end{array}$ & $<0.001$ \\
\hline $\begin{array}{l}\text { Unknown or } \\
\text { CKD5-D }\end{array}$ & & 824 & 263 & 848 & 278 & 480 & \\
\hline AKI in first 7 days & 5,030 & $332(20 \%)$ & $140(25 \%)$ & $262(16 \%)$ & $70(17 \%)$ & $115(19 \%)$ & $<0.001$ \\
\hline $\begin{array}{l}\text { Peak } \\
\text { Creatinine }\end{array}$ & 5,274 & $\begin{array}{c}96 \\
(77,132)\end{array}$ & $\begin{array}{c}112 \\
(84,188)\end{array}$ & $\begin{array}{c}94 \\
(76,134)\end{array}$ & $\begin{array}{c}86 \\
(72,117)\end{array}$ & $\begin{array}{c}93 \\
(75,121)\end{array}$ & $<0.001$ \\
\hline Unknown & & 60 & 26 & 107 & 17 & 49 & \\
\hline Peak CRP & 5,072 & $\begin{array}{c}101 \\
(49,190)\end{array}$ & $\begin{array}{c}111 \\
(52,206)\end{array}$ & $\begin{array}{c}96 \\
(46,185)\end{array}$ & $\begin{array}{c}104 \\
(47,187)\end{array}$ & $\begin{array}{c}112 \\
(54,201)\end{array}$ & 0.10 \\
\hline Unknown & & 125 & 46 & 176 & 39 & 75 & \\
\hline Peak Ferritin & 4,164 & $\begin{array}{c}735(357 \\
1,422)\end{array}$ & $\begin{array}{c}870(457, \\
1,462)\end{array}$ & $\begin{array}{c}718(360 \\
1,359)\end{array}$ & $\begin{array}{c}912(489 \\
1,590)\end{array}$ & $\begin{array}{c}949(449) \\
1,795)\end{array}$ & $<0.001$ \\
\hline Unknown & & 480 & 160 & 417 & 100 & 212 & \\
\hline $\begin{array}{l}\text { Peak } \\
\text { D-dimer }\end{array}$ & 4,301 & $\begin{array}{c}1.54(0.80 \\
4.15)\end{array}$ & $\begin{array}{c}2.23(0.86 \\
8.87)\end{array}$ & $\begin{array}{c}1.21(0.59 \\
4.31)\end{array}$ & $\begin{array}{c}1.27(0.62 \\
7.65)\end{array}$ & $\begin{array}{c}1.80(0.69 \\
7.22)\end{array}$ & $<0.001$ \\
\hline Unknown & & 435 & 159 & 372 & 91 & 175 & \\
\hline ICU admission & 5,533 & $170(9.4 \%)$ & $70(11 \%)$ & $266(13 \%)$ & $62(14 \%)$ & $91(13 \%)$ & $<0.001$ \\
\hline $\begin{array}{l}\text { Death by day } \\
30\end{array}$ & 5,533 & $370(20 \%)$ & $103(16 \%)$ & $355(18 \%)$ & $54(12 \%)$ & $92(14 \%)$ & $<0.001$ \\
\hline $\begin{array}{l}\text { Death by day } \\
90\end{array}$ & 5,533 & $444(25 \%)$ & $128(20 \%)$ & $422(21 \%)$ & $68(16 \%)$ & $108(16 \%)$ & $<0.001$ \\
\hline $\begin{array}{l}\text { Survivors } \\
\text { Hospital } \\
\text { Length of stay } \\
\text { (days) }\end{array}$ & 4529 & $\begin{array}{c}6 \\
(2,13)\end{array}$ & $\begin{array}{c}6 \\
(2,12)\end{array}$ & $\begin{array}{c}5 \\
(2,9)\end{array}$ & $\begin{array}{c}6 \\
(2,12)\end{array}$ & $\begin{array}{c}5 \\
(2,10)\end{array}$ & $<0.001$ \\
\hline $\begin{array}{l}\text { Survivors } \\
\text { Discharged to } \\
\text { usual place of } \\
\text { residence }\end{array}$ & 4529 & $1,268(88 \%)$ & $469(90 \%)$ & $1,524(95 \%)$ & $347(93 \%)$ & $518(90 \%)$ & $<0.001$ \\
\hline
\end{tabular}


medRxiv preprint doi: https://doi.org/10.1101/2021.07.05.21260026; this version posted July 7, 2021. The copyright holder for this preprint (which was not certified by peer review) is the author/funder, who has granted medRxiv a license to display the preprint in perpetuity. It is made available under a CC-BY-NC-ND 4.0 International license .

Table 2: Multivariable modelling (PH: Proportional Hazards, LR: Logistic Regression).

\begin{tabular}{|c|c|c|c|c|c|c|}
\hline & \multicolumn{5}{|c|}{ Second wave } & \multirow{2}{*}{$\begin{array}{c}\text { First wave } \\
\begin{array}{c}1-y e a r \\
\text { survival }\end{array}\end{array}$} \\
\hline Outcome & 30-day mortality & 30-day mortality & 30-day mortality & 90-day mortality & ICU admission & \\
\hline Model & PH & PH & PH & $\mathrm{PH}$ & LR & $\mathrm{PH}$ \\
\hline Number & 4809 & 4809 & 4809 & 4809 & 4809 & 1722 \\
\hline Events & 879 & 879 & 879 & 1057 & 459 & 586 \\
\hline $\begin{array}{l}\text { Age } \\
\left(75^{\text {th }} \text { vs. } 25^{\text {th }} \text { centiles }\right)\end{array}$ & $\begin{array}{c}5.85 \\
(4.93-6.94)\end{array}$ & $\begin{array}{c}5.12 \\
(4.33-6.06)\end{array}$ & $\begin{array}{c}5.09 \\
(4.29-6.02)\end{array}$ & $\begin{array}{c}5.22 \\
(4.48-6.08)\end{array}$ & $\begin{array}{c}0.70 \\
(0.58-0.84)\end{array}$ & $\begin{array}{c}4.33 \\
(3.58-5.24)\end{array}$ \\
\hline Male Sex & $\begin{array}{c}1.44 \\
(1.26-1.66)\end{array}$ & $\begin{array}{c}1.50 \\
(1.31-1.73)\end{array}$ & $\begin{array}{c}1.43 \\
(1.25-1.67)\end{array}$ & $\begin{array}{c}1.38 \\
(1.22-1.57)\end{array}$ & $\begin{array}{c}1.87 \\
(1.54-2.26)\end{array}$ & $\begin{array}{c}1.42 \\
(1.19-1.68)\end{array}$ \\
\hline \multicolumn{7}{|l|}{ Ethnicity } \\
\hline White & Ref & Ref & Ref & Ref & Ref & Ref \\
\hline Asian & $\begin{array}{c}1.47 \\
(1.24-1.73)\end{array}$ & $\begin{array}{c}1.62 \\
(1.38-1.89)\end{array}$ & $\begin{array}{c}1.47 \\
(1.26-1.72)\end{array}$ & $\begin{array}{c}1.41 \\
(1.22-1.64)\end{array}$ & $\begin{array}{c}1.38 \\
(1.10-1.73)\end{array}$ & $\begin{array}{c}1.38 \\
(1.12-1.71)\end{array}$ \\
\hline Black & $\begin{array}{c}1.06 \\
(0.84-1.33)\end{array}$ & $\begin{array}{c}1.16 \\
(0.92-1.45)\end{array}$ & $\begin{array}{c}1.06 \\
(0.85-1.33)\end{array}$ & $\begin{array}{c}1.07 \\
(0.87-1.31)\end{array}$ & $\begin{array}{c}1.09 \\
(0.80-1.48)\end{array}$ & $\begin{array}{c}1.14 \\
(0.90-1.44)\end{array}$ \\
\hline Mixed/Other & $\begin{array}{c}1.03 \\
(0.77-1.39)\end{array}$ & $\begin{array}{c}1.09 \\
(0.81-1.46)\end{array}$ & $\begin{array}{c}1.10 \\
(0.82-1.47)\end{array}$ & $\begin{array}{c}1.06 \\
(0.82-1.38)\end{array}$ & $\begin{array}{c}1.53 \\
(1.11-2.11)\end{array}$ & $\begin{array}{c}1.05 \\
(0.74-1.48)\end{array}$ \\
\hline Smoking & $\begin{array}{c}1.23 \\
(1.03-1.47)\end{array}$ & $\begin{array}{c}1.14 \\
(0.95-1.36)\end{array}$ & $\begin{array}{c}1.14 \\
(0.95-1.36)\end{array}$ & $\begin{array}{c}1.19 \\
(1.01-1.41)\end{array}$ & $\begin{array}{c}0.90 \\
(0.69-1.18)\end{array}$ & $\begin{array}{c}1.20 \\
(0.95-1.51)\end{array}$ \\
\hline Obesity & $\begin{array}{c}1.36 \\
(1.17-1.61)\end{array}$ & $\begin{array}{c}1.44 \\
(1.23-1.69)\end{array}$ & $\begin{array}{c}1.37 \\
(1.17-1.61)\end{array}$ & $\begin{array}{c}1.27 \\
(1.10-1.47)\end{array}$ & $\begin{array}{c}1.63 \\
(1.35-1.98)\end{array}$ & $\begin{array}{c}1.16 \\
(0.97-1.40)\end{array}$ \\
\hline Diabetes & $\begin{array}{c}1.09 \\
(0.94-1.26)\end{array}$ & & & $\begin{array}{c}1.01 \\
(0.89-1.16)\end{array}$ & $\begin{array}{c}1.13 \\
(0.92-1.39)\end{array}$ & $\begin{array}{c}1.28 \\
(1.07-1.53)\end{array}$ \\
\hline$C K D$ & $\begin{array}{c}1.34 \\
(1.16-1.55)\end{array}$ & & & $\begin{array}{c}1.44 \\
(1.26-1.64)\end{array}$ & $\begin{array}{c}0.95 \\
(0.75-1.21)\end{array}$ & $\begin{array}{c}1.39 \\
(1.161 .66)\end{array}$ \\
\hline Hypertension & $\begin{array}{c}1.24 \\
(1.03-1.49)\end{array}$ & & & $\begin{array}{c}1.28 \\
(1.08-1.51)\end{array}$ & $\begin{array}{c}1.46 \\
(1.14-1.87)\end{array}$ & $\begin{array}{c}0.98 \\
(0.78-1.23)\end{array}$ \\
\hline CCIO & & & Ref & & & \\
\hline CCI $1-2$ & & & $\begin{array}{c}2.24 \\
(1.66-3.02)\end{array}$ & & & \\
\hline CCI 3-4 & & & $\begin{array}{c}2.78 \\
(2.04-3.81)\end{array}$ & & & \\
\hline$C C I>5$ & & & $\begin{array}{c}3.62 \\
(2.67-4.91)\end{array}$ & & & \\
\hline$H F R S<5$ & & Ref & & & & \\
\hline HFRS 5-15 & & $\begin{array}{c}2.29 \\
(1.94-2.70)\end{array}$ & & & & \\
\hline$H F R S>15$ & & $\begin{array}{c}2.10 \\
(1.70-2.60)\end{array}$ & & & & \\
\hline$I M D 1$ & Ref & Ref & Ref & Ref & Ref & Ref \\
\hline$I M D 2$ & $\begin{array}{c}0.87 \\
(0.70-1.07)\end{array}$ & $\begin{array}{c}0.84 \\
(0.68-1.04)\end{array}$ & $\begin{array}{c}0.85 \\
(0.69-1.05)\end{array}$ & $\begin{array}{c}0.93 \\
(0.77-1.13)\end{array}$ & $\begin{array}{c}1.0 \\
(0.76-1.32)\end{array}$ & $\begin{array}{c}0.97 \\
(0.75-1.27)\end{array}$ \\
\hline$I M D 3$ & $\begin{array}{c}0.77 \\
(0.62-0.95)\end{array}$ & $\begin{array}{c}0.77 \\
(0.62-0.96)\end{array}$ & $\begin{array}{c}0.77 \\
(0.62-0.95)\end{array}$ & $\begin{array}{c}0.81 \\
(0.67-0.98)\end{array}$ & $\begin{array}{c}0.89 \\
(0.67-1.17)\end{array}$ & $\begin{array}{c}0.87 \\
(0.67-1.14)\end{array}$ \\
\hline$I M D 4$ & $\begin{array}{c}1.01 \\
(0.82-1.24)\end{array}$ & $\begin{array}{c}1.00 \\
(0.82-1.23)\end{array}$ & $\begin{array}{c}1.00 \\
(0.82-1.23)\end{array}$ & $\begin{array}{c}1.05 \\
(0.87-1.27)\end{array}$ & $\begin{array}{c}0.76 \\
(0.57-1.01)\end{array}$ & $\begin{array}{c}0.93 \\
(0.72-1.20)\end{array}$ \\
\hline$I M D 5$ & $\begin{array}{c}0.92 \\
(0.75-1.13)\end{array}$ & $\begin{array}{c}0.92 \\
(0.74-1.13)\end{array}$ & $\begin{array}{c}0.91 \\
(0.74-1.12)\end{array}$ & $\begin{array}{c}0.90 \\
(0.75-1.10)\end{array}$ & $\begin{array}{c}1.00 \\
(0.74-1.32)\end{array}$ & $\begin{array}{c}1.05 \\
(0.81-1.35)\end{array}$ \\
\hline
\end{tabular}


medRxiv preprint doi: https://doi.org/10.1101/2021.07.05.21260026; this version posted July 7, 2021. The copyright holder for this preprint (which was not certified by peer review) is the author/funder, who has granted medRxiv a license to display the preprint in perpetuity. It is made available under a CC-BY-NC-ND 4.0 International license .

Table 3: Hospital admission rates per 100,000 of the age-standardized local population by ethnic group (based on European standard population for ages 15 to $85+$ ).

\begin{tabular}{r|cccc}
\multicolumn{2}{c}{$\begin{array}{c}\text { Admissions/100,000 } \\
\text { Age-Standardized Population }\end{array}$} & $\mathbf{9 5 \% C I}$ & $\begin{array}{c}\text { Ratio vs. White } \\
\text { Ethnicity }\end{array}$ & $\mathbf{9 5 \% ~ C I}$ \\
\hline Wave 1 & & & & \\
White & 239 & $217-260$ & 1.00 & \\
Black & 727 & $641-814$ & $\mathbf{3 . 0 5}$ & $\mathbf{2 . 6 1 - 3 . 5 2}$ \\
Asian & 584 & $529-639$ & $\mathbf{2 . 4 5}$ & $\mathbf{2 . 3 7 - 3 . 0 4}$ \\
Mixed & 225 & $92-358$ & 0.94 & $0.38-1.51$ \\
Other & 898 & $715-1082$ & $\mathbf{3 . 7 6}$ & $\mathbf{2 . 9 4 - 4 . 6 3}$ \\
Wave 2 & & & & \\
White & 532 & $500-563$ & 1.00 & \\
Black & 1,116 & $1017-1216$ & $\mathbf{2 . 1 0}$ & $\mathbf{1 . 8 8 - 2 . 3 3}$ \\
Asian & 2,163 & $2058-2267$ & $\mathbf{4 . 0 7}$ & $\mathbf{3 . 7 7 - 4 . 3 9}$ \\
Mixed & 451 & $295-607$ & 0.85 & $0.55-1.15$ \\
Other & 2,223 & $1947-2499$ & $\mathbf{4 . 1 8}$ & $\mathbf{3 . 6 2 - 4 . 7 7}$ \\
2013-18 & & & & \\
White & 20,056 & $19875-20236$ & 1.00 & \\
Black & 22,403 & $22021-22785$ & $\mathbf{1 . 1 2}$ & $\mathbf{1 . 1 - 1 . 1 4}$ \\
Asian & 26,823 & $26522-27124$ & $\mathbf{1 . 3 4}$ & $\mathbf{1 . 3 2 - 1 . 3 6}$ \\
Mixed & 13,265 & $12633-13896$ & $\mathbf{0 . 6 6}$ & $\mathbf{0 . 6 3 - 0 . 6 9}$ \\
Other & 36,300 & $35381-37220$ & $\mathbf{1 . 8 1}$ & $\mathbf{1 . 7 6 - 1 . 8 6}$
\end{tabular}


medRxiv preprint doi: https://doi.org/10.1101/2021.07.05.21260026; this version posted July 7,2021 . The copyright holder for this preprint

(which was not certified by peer review) is the author/funder, who has granted medRxiv a license to display the preprint in perpetuity. It is made available under a CC-BY-NC-ND 4.0 International license.

\section{Figure legends}

Fig 1: Cox-proportional Hazard analysis included covariates: Age, Sex, Hypertension, Diabetes, Chronic Kidney Disease, Smoking history, Obesity, IMD (quintiles of local study population) for survival over 30 (A) and 90 (B) days in the second pandemic wave ETHICAL cohort.

Fig 2: Predicted survival over 90-days by Ethnicity in a 65-year-old Male living in IMD-3 without Diabetes, CKD, Smoking History, Hypertension or Obesity. Based on second wave Cox-proportional Hazard analysis included covariates: Age, Sex, Hypertension, Diabetes, Chronic Kidney Disease, Smoking history, Obesity, IMD (quintiles of local study population).

Fig 3: Predicted survival by Ethnicity in a 65-year-old Male living in IMD-3 without Diabetes, CKD, Smoking History, Hypertension or Obesity based on 12-month follow-up of the first pandemic wave ETHICAL population in a Cox-proportional Hazard analysis stratified by ethnicity. Included covariates: Age, Sex, Hypertension, Diabetes, Chronic Kidney Disease, Smoking history, Obesity, IMD (quintiles of local study population). Excess mortality associated with Asian ethnicity has persisted over follow up while early survival disadvantage associated with Black ethnicity has attenuated with longer follow-up. Other/Mixed group omitted for clarity.

Fig 4: Numbers of first admissions to Barts Health hospitals in residents of the London Boroughs of Tower Hamlets, Newham, and Waltham Forest aged $\geq 16$, grouped by age and ethnicity for the first and second waves of COVID-19 (panels A \& B) or any acute admissions during 2013-18 (panel C). Age and Ethnicity distribution of the Tower Hamlets, Newham, and Waltham Forest population in the 2011 UK Census is shown for comparison (panel D). 
medRxiv preprint doi: https://doi.org/10.1101/2021.07.05.21260026; this version posted July 7, 2021. The copyright holder for this preprint (which was not certified by peer review) is the author/funder, who has granted medRxiv a license to display the preprint in perpetuity. It is made available under a CC-BY-NC-ND 4.0 International license.

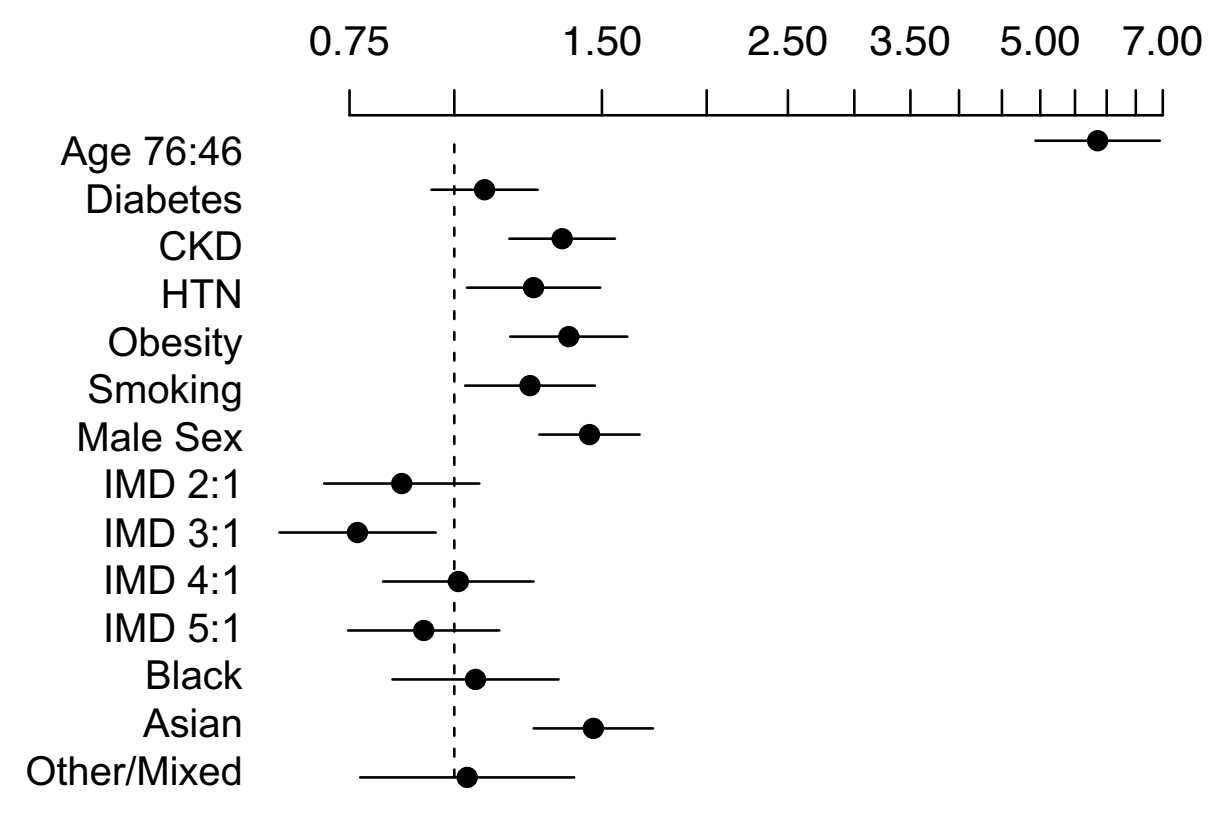

B

Hazard Ratio

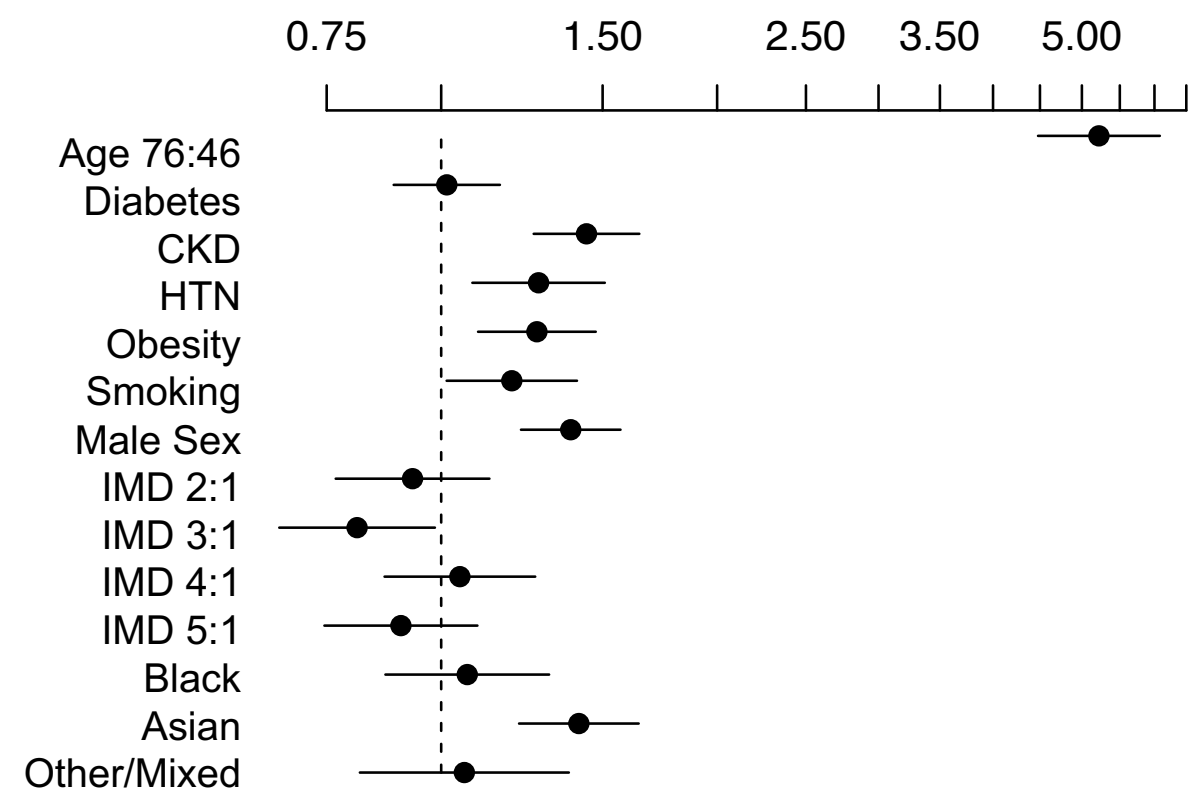

Fig 1: Cox-proportional Hazard analysis included covariates: Age, Sex, Hypertension, Diabetes, Chronic Kidney Disease, Smoking history, Obesity, IMD (quintiles of local study population) for survival over 30 (A) and 90 (B) days in the second pandemic wave ETHICAL cohort. 
medRxiv preprint doi: https://doi.org/10.1101/2021.07.05.21260026; this version posted July 7 , 2021. The copyright holder for this preprint (which was not certified by peer review) is the author/funder, who has granted medRxiv a license to display the preprint in perpetuity. It is made available under a CC-BY-NC-ND 4.0 International license.

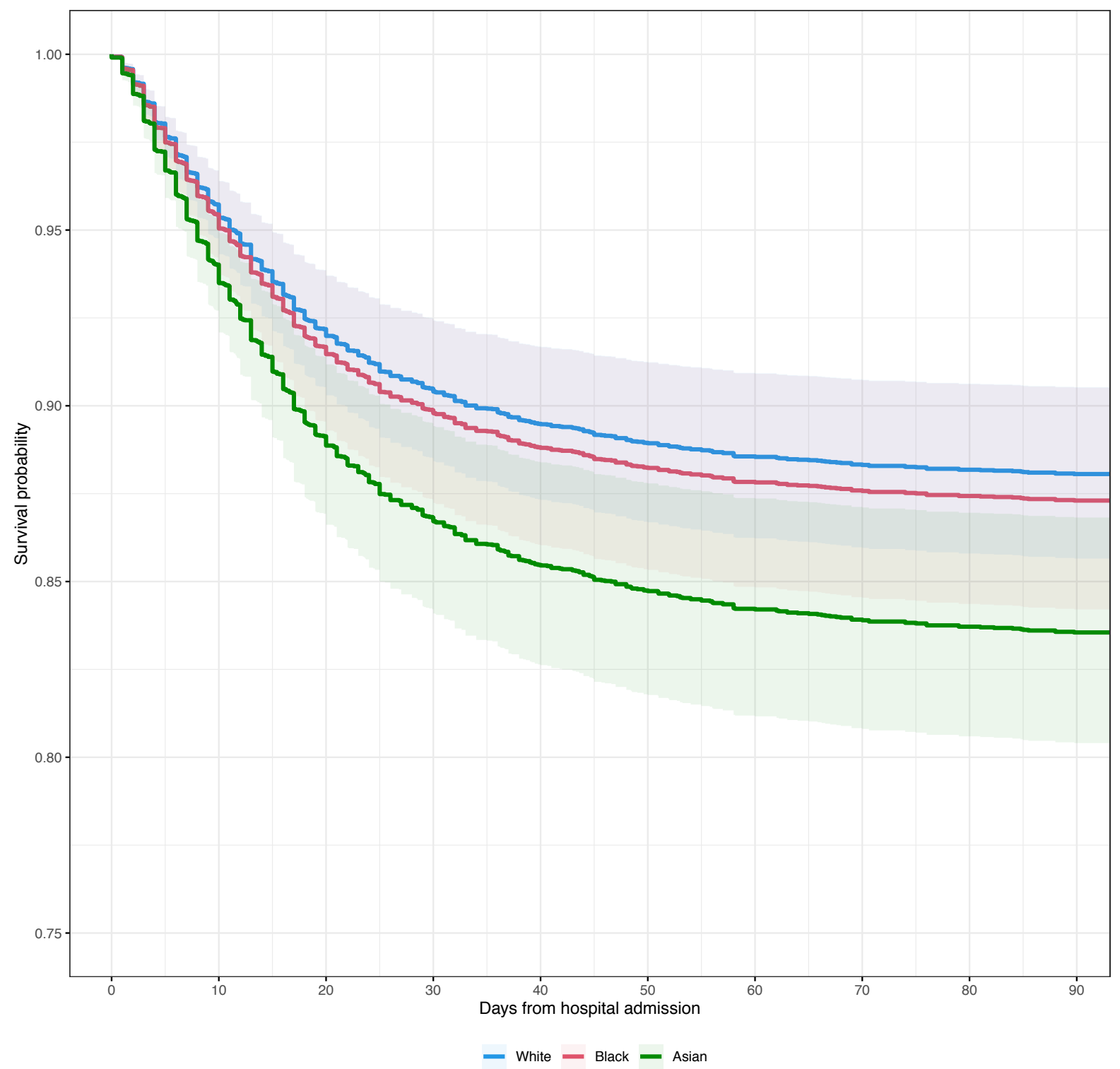

Fig 2: Predicted survival over 90-days by Ethnicity in a 65-year-old Male living in IMD-3 without Diabetes, CKD, Smoking History, Hypertension or Obesity. Based on second wave Cox-proportional Hazard analysis included covariates: Age, Sex, Hypertension, Diabetes, Chronic Kidney Disease, Smoking history, Obesity, IMD (quintiles of local study population). 
medRxiv preprint doi: https://doi.org/10.1101/2021.07.05.21260026; this version posted July 7, 2021. The copyright holder for this preprint (which was not certified by peer review) is the author/funder, who has granted medRxiv a license to display the preprint in perpetuity. It is made available under a CC-BY-NC-ND 4.0 International license.

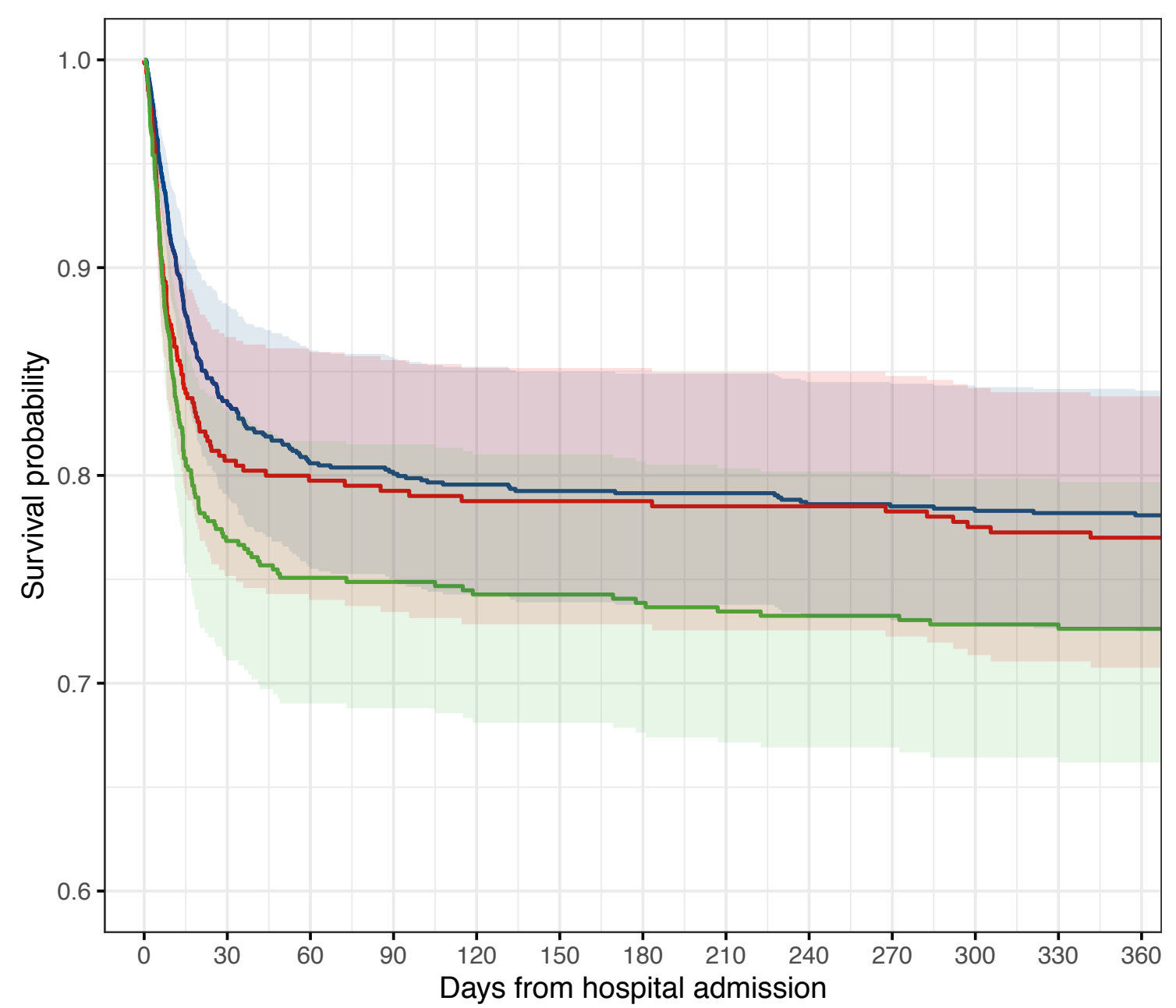

White - Black - Asian

Fig 3: Predicted survival by Ethnicity in a 65-year-old Male living in IMD-3 without Diabetes, CKD, Smoking History, Hypertension or Obesity based on 12-month follow-up of the first pandemic wave ETHICAL population in a Cox-proportional Hazard analysis stratified by ethnicity. Included covariates: Age, Sex, Hypertension, Diabetes, Chronic Kidney Disease, Smoking history, Obesity, IMD (quintiles of local study population). Excess mortality associated with Asian ethnicity has persisted over follow up while early survival disadvantage associated with Black ethnicity has attenuated with longer follow-up. Other/Mixed group omitted for clarity. 
medRxiv preprint doi: https://doi.org/10.1101/2021.07.05.21260026; this version posted July 7, 2021. The copyright holder for this preprint (which was not certified by peer review) is the author/funder, who has granted medRxiv a license to display the preprint in perpetuity. It is made available under a CC-BY-NC-ND 4.0 International license .

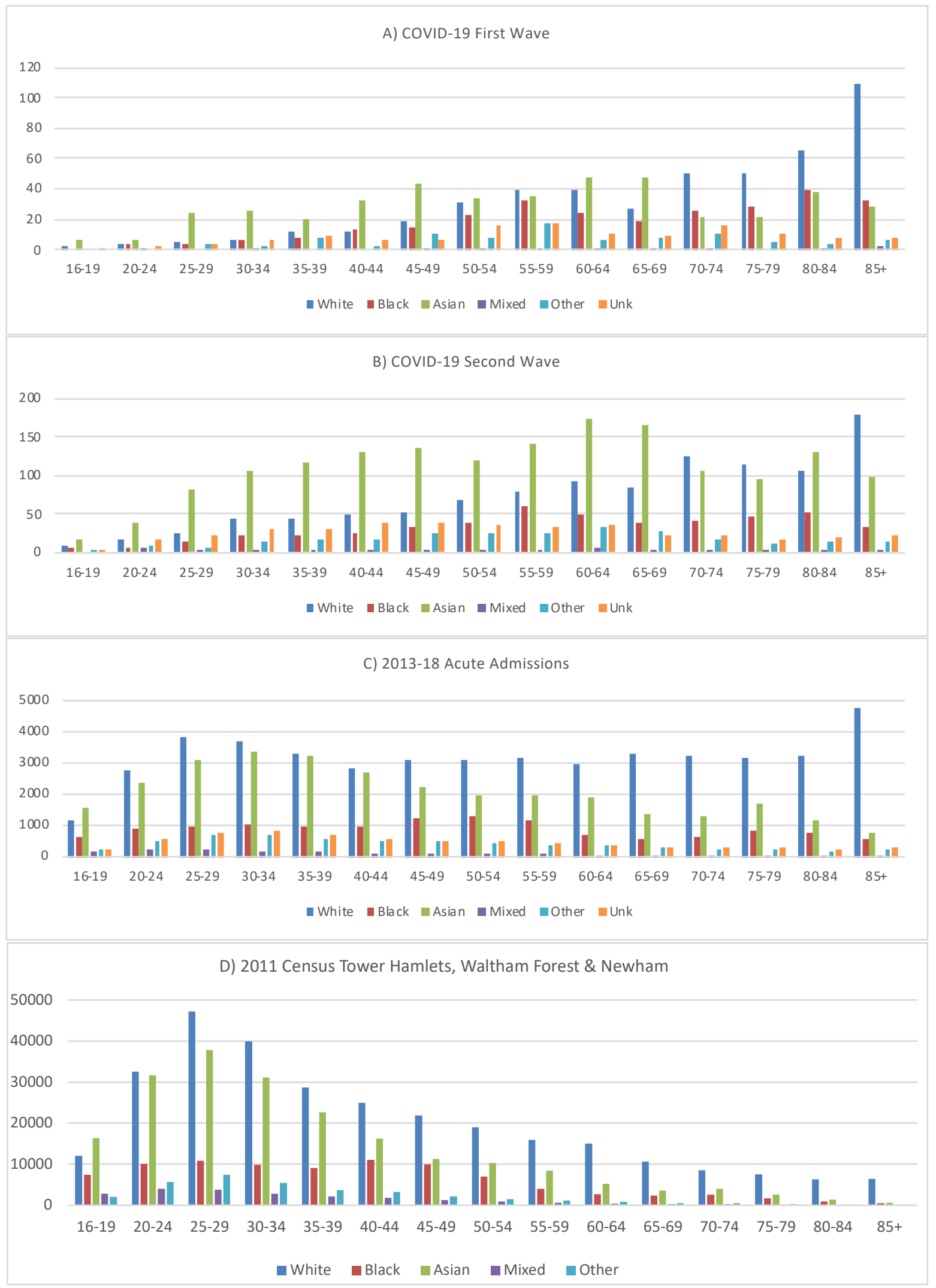

Fig 4: Numbers of first admissions to Barts Health hospitals in residents of the London Boroughs of Tower Hamlets, Newham, and Waltham Forest aged $\geq 16$, grouped by age and ethnicity for the first and second waves of COVID-19 (panels A \& B) or any acute admissions during 2013-18 (panel C). Age and Ethnicity distribution of the Tower Hamlets, Newham, and Waltham Forest population in the 2011 UK Census is shown for comparison (panel D). 